\title{
PUBLIC AND BUSINESS ACTORS' UNDERSTANDING OF GASTRONOMY
}

\author{
Faisal Akbar Zaenal, Muhammad Musawantoro and Lily Dianafitry \\ Politeknik Pariwisata Makassar, Indonesia
}

\begin{abstract}
The purpose of this study was to determine the understanding of the community and business actors regarding the gastronomy of traditional food. The research method used is qualitative research methods. This research was conducted in South Sulawesi. This study uses the approach used to collect data, namely interviews, observation, and documentation. The results showed that business actors were selling their snacks who did not understand how to cook in a good way. There are snacks scattered from various regions but only a few have a distinctive character. Some people see food as a commodity, not a part of the culture. So that they sharpen the advertisement everywhere, but do not see the character of the food that will be marketed. As a result, they didn't wait long for the stall, which was usually crowded with people. Some business actors still believe in the traditional culinary business being run. Some food stalls uphold their belief by providing traditional food menus. Starting from simple stalls to fairly large food stalls. Various ethical issues arise as a challenge in developing traditional culinary businesses, especially in South Sulawesi. Mindset is sometimes also one of the main reasons why traditional food is not so big on the market compared to modern food.
\end{abstract}

Key words: Understanding Gastronomy, Society, Business Actors

Cite this Article: Faisal Akbar Zaenal, Muhammad Musawantoro and Lily Dianafitry, Public and Business Actors' Understanding of Gastronomy, International Journal of Management, 11(12), 2020, pp 1990-1996.

http://iaeme.com/Home/issue/IJM?Volume=11\&Issue=12

\section{INTRODUCTION}

Determination of identification and classification of traditional culinary can be seen that culinary can be in the form of food, drinks, and snacks or snacks. Food can be distinguished from daily food, traditional and traditional foods related to life cycle commemoration, and food for ritual ceremonies as offerings (Cen \& He, 2007; Luykx \& Van Ruth, 2008). Drinks consist of soft drinks in daily activities as well as for traditional ceremonies and receptions, there are also herbs for health therapy and healthy drinks that are consumed as fresh drinks. This classification is an identification of materials, benefits, and values. Culinary is a part of 
humans, culture, and the environment. From a cultural perspective, it is an identity, representation, and production of culture that develops in society. The dietary pattern and type of food of the community can describe life behaviors such as health, lifestyle, environment, and supporting community social systems (Loring \& Gerlach, 2009; Hale et al., 2011). Culinary culture, depicting local identity, a cultural supporter that characterizes the environment and habits. Also describes representation, regulation, consumption, and production. Culinary is a representation of resistance from among the people with various interpretations. Likewise, it shows the social, economic, and class backgrounds of consumers. Therefore, in the culinary process, a community is managed by customary regulations that contain recommendations, taboos, and ethics on how to use them.

Culinary products not only display "special foods" but can develop into a medium for interpretation that broadens the horizons of tourists. This insight not only revolves around what flavors or spices are used in a dish but also increases knowledge about eating methods, lifestyle, traditions, culture, history, to the geographical elements represented through the presentation and taste of the dish.

An example of the close connection between food and geographic elements is reflected in the serving of Cirebon's signature fried liver sauce wrapped in teak leaves. This implies that this hot area is physically rich in teak trees. The same reason can be seen from the Menadostyle spiced chicken which is steamed using long bamboo. This can inform the abundance of bamboo trees in Minahasa soil within a certain time frame.

Gastronomy is the art or science of good food. A shorter explanation mentions gastronomy as everything related to the enjoyment of eating and drinking (Myhrvold, 2011). Based on this theory, gastronomy can be explained as a study of the relationship between culture and food, in which gastronomy studies various components of culture with food as the center (culinary arts) (Scarpato, 2002; Santich, 2004). Gastronomic coverage does not only look at food in terms of meeting physiological needs but the assessment of food as an aspect of culture and an asset for the region.

Gastronomy is also the main motive behind the actors who prepare and who move until the availability of food and beverage ingredients, such as cultivators, fishermen farmers, animal hunters, cooks, or whatever their title or qualification is (Hegarty \& O'Mahony, 2001; Kivela \& Crotts, 2006).

According to Santich (2004), Gastronomy is a guide regarding various ways that involve everything about food and drink. The study is very interdisciplinary related to the reflection of history, cultural impact, and environmental atmosphere regarding "How, where, when, and why. Gastronomy or culinary is the art or science of good food (Good eating).

From a long time ago, Indonesian society was not only rich in a variety of dishes culinary and cooking techniques but also, history, culture and diet, even to the legends and philosophy behind the food. Until now, no culinary become a national identity that can distinguish the Indonesian nation from the other nation. Archipelago culinary is an example that has been passed down from generation to generation in a particular

collection as one of the cultural product identities of the diversity of communities has agreed to unite in the Indonesian state.

South Sulawesi Province is one of the largest provinces in Indonesia with several tribes living in it, such as the Bugis, Makassarese, and Toraja ethnic groups and various languages such as Bugis, Makassarese, Toraja, Konjo, and Enrekang languages. Of the several types of ethnicity, language, customs, culture, and food, only the Bugis and Makassar ethnic groups have the same traditional food, although there are differences in the pronunciation. 
In the presentation of traditional foods in traditional ceremonies in the BugisMakassar tribe community, there are noble values and symbols of meaning. These noble values and symbols of meaning reveal the deepest aspects of reality that are not accessible to other means of recognition. Pictures, symbols, and rituals reveal which modalities are most secretive. His studies opened the way to get to know humans before they were woven into historical events.

\section{METHODS}

The research method used is qualitative research methods. This research was conducted in South Sulawesi. The timing of this research was carried out from January-April 2020. The data sources and types of data consisted of words and actions, written data sources, photos, and statistics (Moleong, 2017). This study uses the approach used to collect data, namely interviews, observation, and documentation.

The data analysis process begins by examining all available data from various sources, namely from interviews, observations that have been written in field notes, personal documents, official documents, pictures, photos, and so on. After reading, studying, and analyzing, the next step is to reduce the data by doing an abstraction. Abstraction is an attempt to create a core summary, process, and questions that need to be kept in it. The next step is to arrange it in units. The units are categorized in the next step. These categories are created while coding. The final stage of this data analysis is to check the validity of the data.

\section{RESULTS AND DISCUSSION}

Food is related to people's lives and business actors. In society, food is part of social capital. European and American food seems to be high-class food, while local food becomes middleto-lower class food. The existence of this perception affects the market segmentation for traditional food which is starting to lose competition from "modern" food. People are more prestigious and like to eat crispy chicken from America, compared to nasu likku (traditional cuisine) from Bugis ethnicity. Pizza from Italy, and kalimbu (traditional cuisine) from Bugis ethnicity and so on. As a result, business actors, especially traditional hawker sellers, have to struggle with food from Europe and America. This chapter discusses people's understanding of gastronomy and business actors as well as gastronomy.

\section{PUBLIC UNDERSTANDING OF GASTRONOMY}

Talking about people's understanding of gastronomy can be said to be still limited. There are business actors selling snacks who do not understand how to cook in a good way. There are snacks scattered from various regions but only a few have a distinctive character. Therefore, this character is still preserved until now, making his snacks salable. For example, the Pallubasa cuisine found on Jalan Serigala Makassar is quite crowded with local, national, and even international tourists. What's the secret? They retained the recipe of their ancestors which has been preserved until now.

Peddling flavors means peddling the character of the dish. Some people see food as a commodity, not a part of the culture. So that they sharpen the advertisement everywhere, but do not see the character of the food that will be marketed. As a result, they didn't wait long for the stall, which was usually crowded with people. A student who is in the business world is not much about gastronomy. Ali Tahir (2020) as a person who sells yellow rice, always walks around every morning but is more marketable than those who have been trolled for a long time. Because they don't see food as taste but a commodity.

National identity is the same as national identity. identity comes from the English language, namely "identity" which means the characteristics, signs, and identity attached to a 
person or social group. So it can be concluded that national identity is a characteristic, sign, or national identity that is different from other nations. Indonesian national identity that distinguishes it from other nations, among others, the Pancasila ideology as the basis of philosophy, view of life, and the basis of the state. The definition of national identity is manifested by cultural values that grow and develop in the aspects of the life of a nation or country with the characteristics of a nation. The potential in each region in Indonesia to elevate gastronomic culinary as an identity is very large by utilizing local wisdom because in local gastronomic wisdom it can be used as one of the local indicators based on culture with traditions in various regions that are formed as the superiority of the local culture. respectively. Local wisdom in gastronomic culinary contains a system of beliefs, norms, and culture which is shown in traditions that are passed down from generation to generation. The policy in Indonesian culinary emphasizes more on local gastronomy in preserving the traditional heritage of dishes from ancestors whose rituals, religious values, philosophies, identities, and national roots (Krisnadi, 2018).

This qualitative understanding can serve as a basic reference that there are large numbers of people who do not understand deeply about gastronomy, the most important commodities. So that business builders are what the community wants, not based on community culture.

\section{BUSINESS ACTORS AND GASTRONOMY}

Culinary for the general public is considered only as a ritual of eating and drinking, delicious and unpleasant, appropriate and unfit for consumption of these foods, from this foundation eating began to emerge several culinary industries that only pay attention to commercial issues (Musawantoro \& Ridwan, 2019). Various kinds of food and beverage menus are offered in the culinary world, ranging from those that are ready to eat and those that are packaged.

Modern culinary delights are used for consumption by the public, as satisfying hunger, prestige, the present, some even more extreme culinary is sometimes used as a symbol of privacy status, not infrequently culinary too (Rijal, Fitry, \& Zaenal, 2020). In terms of marketing, modern culinary delights tend to be easier so that it becomes an opportunity for people who want to move to the culinary industry.

In contrast to traditional culinary, it is often underestimated because traditional culinary from its packaging and presentation is less attractive besides that it also has a slightly strong taste so it is not suitable for some culinary connoisseurs in general, this is what makes culinary industry players sometimes get lethargic in the market free.

The strong character that emerges from traditional culinary is inseparable from the basic gastronomic relationship because this traditional culinary exists because of the connection between historical, customary, symbolic values, as well as local wisdom. If this matter is considered and used as a basis in managing a business or traditional culinary business, especially cultural values, it is possible that traditional culinary businesses will increase properly.

Traditional culinary food is important to be preserved. Basically, traditional food can be introduced because it has a variety of delicious flavors. Not only this but behind traditional food, especially in South Sulawesi, it contains noble philosophical values that have been passed down from generation to generation from ancestors to royal life which is the source and guide of life. The noble values contained behind the traditional food referred to are such as respect for diversity, a blessing of gratitude, respect for fellow humans and creators as well as other noble values. This can be emphasized by traditional culinary business actors to increase selling value.

Various ethical issues arise as a challenge in developing traditional culinary businesses, especially in South Sulawesi. Mindset is sometimes also one of the main reasons why traditional food is not so big on the market compared to modern food. This is because social 
class affects food consumption habits. The urban style of culinary life has become ethical issue that need to be resolved.

However, in the midst of the upheaval between traditional food and modern food. Some business actors still believe in the traditional culinary business being run. Some food stalls uphold their belief by providing traditional food menus. Starting from simple stalls to fairly large food stalls. In South Sulawesi, in certain areas such as Makassar City, there are still many traditional culinary businesses. For culinary, traditional cakes are still often found in some cake shops. Some traditional cakes such as cukke cake, onde-onde, bowsprit cake are not only available on sacred events such as weddings but thanksgiving events, as well as formal events. Although not so much, it can be concluded that the existence of traditional cakes still has a place and deserves to be further developed. The need for strategic steps for business actors. One of the traditional foods that also exist in the culinary world in South Sulawesi is pallumara (traditional cuisine), which is served in several food stalls in Pangkajene and Islands Regencies. Pallumara, which is processed from sponge fish which is the hallmark of Pangkep Regency, is a traditional culinary dish that still exists today. Most food stalls provide a pallumara (traditional cuisine) menu to be served. Enthusiasts do not only come from regional origins but also come from tourists who usually travel to visit an area who then have lunch in Pangkajene and Islands Regencies. In addition to the characteristics of traditional food, recipes from ancestors make different tastes and of course delicious in eating pallumara which has been a traditional food for generations. Its historical value and taste keep it alive in the culinary world.

The influence of the relationship between knowledge (history) possessed by gastronomy on the potential development of a traditional food business is certainly an important asset in developing a business. Although recipes from traditional food come from ancestors that are carried out from generation to generation, sometimes each actor has a different way and its own secret in making traditional food. The art of cooking, procedures, and the values of knowledge seems to be a sacred process in making traditional food which makes it have more value than other foods. Made with the intention and traditional ways. The materials used, as explained above, are sugar, coconut, and rice which have their own symbolic meaning. Besides the symbolic meaning and taste that is owned, such sweet sugar is processed into traditional food. So that it produces a different taste, so delicious that is wrapped with an appetizing taste. This can be a standout point compared to other foods.

Then, when talking about the packaging of traditional food that looks different from other foods, it is more of a special attraction for culinary connoisseurs. Packaging with more traditional value, such as sokko' wrapped in banana leaves, as well as barongko has its own charm. Just need to modify it so that it is more attractive but does not leave or change the form of the traditional food. Traditional food offerings have a selling value when used as business packaging. Seeing some activities now that in addition to traditional events such as weddings, thanksgiving, traditional food has also become a part that is served on certain formal occasions.

Along with the progress of the increasingly modern times, we will find several westernstyle restaurants. In the image structure, that eating western-style food is considered by the community to be in an upper-class order compared to eating traditional culinary foods which some people think will be classified as the lower class. With gastronomy, we can find out how to keep culinary or traditional dishes awake and can be enjoyed and liked by various groups. Gastronomy is closely related to developing and supporting culinary preservation. Moreover, South Sulawesi is one of the provinces that has a culinary wealth not only in terms of delicacy but also from its historical side which has its own symbolic meaning. This is sufficient to serve as a greater potential. 
On the other hand, even though there are many tourists and even foreign tourists who always miss Indonesian culinary. There are many natural resources available in the fulfillment or manufacture of traditional foods that have a taste that is always missed. This proves that traditional food has a place for its development. This can be seen regarding tourist satisfaction regarding the dishes served. Of course, when you want to compete with modern cuisine, there must be the development of product offerings. But it does not leave the historical value and traditional taste. According to Buchrin (2000: 101) states that the goal of product development is to meet the desires of unsatisfied consumers, win the competition by utilizing production resources, increase profits by using the same material, utilize waste materials and improve products and packaging. This is used as a strategy in the development of traditional food as a culinary tourism attraction. This study is very important considering traditional food is one of the products offered and is expected to be a culinary tourism attraction.

Culinary has become an important role in promoting Indonesian tourism and Indonesian culture as one of the attractions of tourism as well as being one of the creative economy subsectors (Wijaya, 2019; Syahrial \& Badollahi, 2020; Amiruddin, 2020). This is an opportunity to promote and improve the image of tourism and gastronomic midwife. On the other hand, Indonesia is one of the world's culinary surges which is supported by the location of the archipelago which is fertile in producing natural resources as quality food ingredients.

\section{CONCLUSION}

The influence of the relationship between knowledge (history) possessed by gastronomy on the potential development of a traditional food business is certainly an important asset in developing a business. Although recipes from traditional food come from ancestors that are carried out from generation to generation, sometimes each actor has a different way and its own secret in making traditional food. It can be said that people's understanding of gastronomy is still limited. There are business actors selling snacks who do not understand how to cook in a good way. There are snacks scattered from various regions but only a few have a distinctive character. Some people see food as a commodity, not a part of the culture. So that they sharpen the advertisement everywhere, but do not see the character of the food that will be marketed. As a result, they didn't wait long for the stall, which was usually crowded with people. Some business actors still believe in the traditional culinary business being run. Some food stalls uphold their belief by providing traditional food menus. Starting from simple stalls to fairly large food stalls.

\section{REFERENCES}

[1] Amiruddin, H. (2020). Strategy in Promotion E-Tourism Base: Study on Bantaeng Regional Government. Journal La Bisecoman, 1(1), 1-6.

[2] Khan, B. (2020). The Impact of the Second National Fadama Development Project on Poverty

[3] Reduction in the Geidam Local Government of Yobe State, Nigeria. Journal of Advanced Research in Economics and Administrative Sciences, 1(2), 30-44. https://doi.org/10.47631/jareas.v1i2.32

[4] Cen, H., \& He, Y. (2007). Theory and application of near infrared reflectance spectroscopy in determination of food quality. Trends in Food Science \& Technology, 18(2), 72-83.

[5] Hale, J., Knapp, C., Bardwell, L., Buchenau, M., Marshall, J., Sancar, F., \& Litt, J. S. (2011). Connecting food environments and health through the relational nature of aesthetics: Gaining insight through the community gardening experience. Social science \& medicine, 72(11), 1853-1863. 
[6] Hegarty, J. A., \& O’Mahony, G. B. (2001). Gastronomy: A phenomenon of cultural expressionism and an aesthetic for living. International Journal of Hospitality Management, 20(1), 3-13.

[7] Kivela, J., \& Crotts, J. C. (2006). Tourism and gastronomy: Gastronomy's influence on how tourists experience a destination. Journal of hospitality \& tourism research, 30(3), 354- 377.

[8] Loring, P. A., \& Gerlach, S. C. (2009). Food, culture, and human health in Alaska: an integrative health approach to food security. Environmental Science \& Policy, 12(4), 466-478.

[9] Luykx, D. M., \& Van Ruth, S. M. (2008). An overview of analytical methods for determining the geographical origin of food products. Food chemistry, 107(2), 897-911.

[10] Myhrvold, N. (2011). The art in gastronomy: A modernist perspective. Gastronomica: The Journal of Food and Culture, 11(1), 13-23.

[11] Muhrifan, A., Citrakesumasari, C., Djide, N. ., Sirajuddin, S. ., Jafar, N. ., \& Naiem, F.

[12] (2020). Differences of Oleic Acid Levels in Breast Milk of Lactating Mothers with Chronic Energy Deficiency (CED) and Normal Status . Journal of Scientific Research in Medical and Biological Sciences, 1(2), 161-170. https://doi.org/10.47631/jsrmbs.v1i2.142

[13] Santich, B. (2004). The study of gastronomy and its relevance to hospitality education and training. International journal of hospitality management, 23(1), 15-24.

[14] Scarpato, R. (2002). Gastronomy as a tourist product: The perspective of gastronomy studies. Tourism and gastronomy, 51-70.

[15] Syahrial, S., \& Badollahi, M. Z. (2020). Development of a Community-Based Marine Tourism Attraction in the Samboang Beach in Bulukumba Regency. Journal La Bisecoman, 1(2), 1-9.

[16] Wijaya, S. (2019). Indonesian food culture mapping: a starter contribution to promote Indonesian culinary tourism. Journal of Ethnic Foods, 6(1), 9. 